\title{
MODEL PEMBERDAYAAN KELOMPOK REMAJA PENGGIAT LITERASI MEDIA MELALUI EDUKASI DAN FASILITASI TEKNOLOGI
}

\author{
Rila Setyaningsih ${ }^{*}$, Abdullah², Nur Aini Shofiya Asy'ari ${ }^{3}$
}

1 Program Studi Ilmu Komunikasi, Universitas Darussalam Gontor 2Program Studi Ilmu Komunikasi, Universitas Darussalam Gontor

3Program Studi Ilmu Komunikasi, Universitas Darussalam Gontor

\begin{abstract}
Abstrak
Kegiatan literasi media yang lebih massif sangatlah penting dilakukan. Berdasarkan pengamatan di lapangan oleh tim pengabdian, kegiatan literasi media masih menemui beberapa kendala terkait minimnya pengetahuan dan pemahaman mengenai pelaksanaan literasi media itu sendiri. Di sisi lain perlu adanya penggiat literasi media yang mampu membuat sebuah sistem sehingga kegiatan literasi media dapat dilaksanakan dengan lebih mudah dan berkelanjutan. Untuk menyelesaikan masalah tersebut, tim pengabdian telah merancang strategi dengan membentuk kelompok remaja penggiat literasi media yang terdiri dari para mahasiswa di Karesidenan Madiun (Pacitan, Ngawi, Magetan, Madiun, Ponorogo). Langkah selanjutnya berupa edukasi tentang literasi media dalam bentuk TOT (training of trainers) dan fasilitasi teknologi. Dengan terbentuknya kelompok tersebut, diharapkan kegiatan literasi media dapat berjalan lebih massif, berkelanjutan, dan terkontrol. Tujuan dari kegiatan ini adalah (1) terbentuknya kelompok penggiat literasi media, (2) Literasi media lebih dikenal oleh masyarakat sehingga masyarakat semakin cerdas dalam bermedia. Hasil dari kegiatan ini berupa terbentuknya kelompok remaja penggiat literasi media di Karesidenan Madiun yang kegiatannya melakukan sosialisasi literasi media di berbagai sekolah dan kelompok masyarakat.

Keywords:

Literasi media, edukasi, fasilitasi teknologi
\end{abstract}

\section{Pendahuluan}

Program kegiatan pengabdian masyarakat ini ditujukan kepada kelompok mahasiswa yang tergabung dalam Perhumas Muda Pawitandirogo (Perhimpunan Hubungan Masyarakat Indonesia Muda Cabang Pacitan, Ngawi Magetan, Madiun, Ponorogo) yang terletak di Jalan Budi Utomo, No 37, Ponorogo. Perhumas Muda Pawitandirogo merupakan kelompok mahasiswa di daerah Pacitan, Ngawi, Magetan, Madiun, dan Ponorogo yang aktif dalam mempelajari dunia public relations. Asosiasi ini lahir pada bulan November tahun 2015. Adapun salah satu program kerja dari Perhumas Muda Pawitandirogo periode 2015-2017 adalah program literasi media.

Selain Perhumas Muda Pawitandirogo, mitra 2 dari program pengabdian masyarakat ini adalah IMIKI (Ikatan Mahasiswa Ilmu Komunikasi Indonesia) Cabang Madiun yang berada di Jalan Raya Siman, Km. 06 Siman, Ponorogo, Jawa Timur. IMIKI Cabang Madiun berdiri berdasarkan SK MENKUMHAM RI No: C-598. HT. 03. 01-Tahun 2005 dengan Akta Notaris Maria Shopia, SH., M.Kn. IMIKI Cabang Madiun merupakan sebuah asosiasi mahasiswa ilmu komunikasi Indonesia yang berada di Karesidenan Madiun yang terdiri dari 4 kampus yakni STISIP Madiun, UNMER Madiun, Universitas Muhammadiyah Ponorogo, dan UNIDA Gontor. Adapun program kerja yang dirancang oleh IMIKI Cabang Madiun meliputi roadshow kampus, sosialisasi pada kegiatan OSPEK mahasiswa baru di setiap kampus anggota, seminar dan workshop komunikasi, dan juga literasi media.

Berdasarkan hasil observasi lapangan dan wawancara yang dilakukan dengan pengurus Perhumas Muda Pawitandirogo dan IMIKI Cabang Madiun sudah memiliki program kerja dalam bidang literasi media akan tetapi belum dapat terlaksana dikarenakan beberapa kendala. Minimnya pengetahuan dan kketerampilan serta fasilitas pelatihan menjadi hal yang tidak dapat dikesampingkan dalam kegiatan literasi media kepada masyarakat. Disamping itu konsistensi pelaksanaan kegiatan yang tidak menentu juga menjadi penghambat terealisasinya program tersebut. 
Berdasarkan analisis situasi dapat teridentifikasi beberapa permasalahan yang dihadapai oleh mitra, yaitu

a. Kedua mitra kesulitan dalam merealisasikan program kerja tentang literasi media dikarenakan fasilitas berupa teknologi yang belum dimiliki sebagai inventaris

b. Pengetahuan dan keterampilan mitra tentang sistem dan strategi penyuluhan literasi media kepada masyarakat yang masih minim.

c. Kurangnya motivasi dalam menjaga kekompakan kelompok. Hal tersebut berdampak pada konsistensi kegiatan literasi media yang diagendakan.

\section{METODOLOGI}

\section{Solusi yang ditawarkan}

Informasi mengenai beberapa permasalahan yang dihadapi oleh mitra 1 dan 2 tersebut pastinya harus diatasi sesegera mungkin. Tim pengusul pengabdian sebagai bagian dari masyarakat merasa terpanggil untuk ikut membantu memberikan solusi terhadap permasalahan yang sedang dihadapi oleh kedua mitra. Melalui program usulan kegiatan pengabdian masyarakat ini dan berdasarkan analisis kebutuhan yang telah dilaksanakan, tim pengabdian mencoba menawarkan solusi terhadap permasalahan tersebut melalui kegiatan sebagai berikut:

a. Pembentukan kelompok remaja penggiat melek media literasi

Kegiatan tersebut bertujuan untuk membentuk sebuah komunitas yang peduli terhadap literasi media dan sebagai agen literasi media khususnya di daerah Madiun dan sekitarnya.

b. Pelatihan, pendampingan penyuluhan literasi media, dan fasilitasi teknologi

Hal ini sangat penting dilakukan karena menimbang pentingnya literasi media sehingga dikenal oleh masyarakat secara luas yang apada akhirnya masyarakat sadar dan peduli terhadap pemanfaatan media dengan baik dan benar.

\section{Mekanisme Pelaksanaan Kegiatan IbM}

Pelaksanaan kegiatan ini dilakukan dengan dengan 3 tahapan, yaitu: perencanaan, proses, monitoring dan evaluasi. Aktivitas-aktivitas dari masing-masing tahapan adalah sebagai berikut.

a. Perencanaan

Kegiatan yang dilaksanakan pada tahap perencanaan adalah:

1) Pembentukan kelompok remaja penggiat literasi media

Tim pelaksana diundang untuk mengadakan pertemuan persiapan pelaksanaan kemudian diberikan pembekalan terkait dengan maksud, tujuan, mekanisme program, dan hal-hal yang berkaitan dengan metode/teknik pelaksanaan.

2) Sosialisasi program kepada dua mitra (khalayak sasaran)

Sosialisasi dilakukan dalam bentuk koordinasi dengan mengundang semua anggota Perhumas Muda Pawitandirogo dan IMIKI Cabang Madiun sebagai mitra berkaitan dengan program yang akan dilaksanakan. Kegiatan sosialisasi tersebut dilakukan oleh Tim Pelaksana pengabdian dan didampingi oleh LPPM Universitas Darussalam Gontor.

3) Penyusunan program pelatihan

Berdaskan hasil identifikasi, hasil analisis permasalahan pada mitra 1 dan 2, hasil analisis kebutuhan, dan hasil analisis potensi mitra, selanjutnya disusun progam pelatihan (edukasi) bagi kelompok remaja penggiat melek media literasi.

\section{b. Proses}

Proses dalam kegiatan ini berupa implementasi Program. Kegiatan yang akan dilakukan untuk mengimplementasikan program pengabdian adalah (a) meningkatkan pengetahuan dan keterampilan kelompok remaja dalam kegiatan edukasi literasi media dalam bentuk TOT, (b) memberikan fasilitas teknologi yang digunakan dalam kegiatan penyuluhan literasi media, (c) pembinaan dan pelatihan dalam menjaga konsistensi dan kekompakan kelompok.

\section{c. Monitoring dan Evaluasi}

Monitoring dilakukan terhadap proses penyuluhan literasi media kepada masyarakat yang diterapkan oleh kelompok remaja penggiat literasi media. Evaluasi dilakukan terhadap kuantitas dan kualitas penyuluhan literasi media. Kuantitasnya dapat dilihat dari frekuensi penyuluhan dan jumlah peserta, sedangkan kualitasnya terlihat dari meningkatnya pengetahuan literasi masyarakat. 


\section{HASIL PENGABDIAN}

Pelaksanaan kegiatan pengabdian masyarakat mempunyai target terbentuknya kelompok remaja penggiat literasi media yang kegiatannya adalah melakukan sosialisasi literasi media di sekolah-sekolah dan masyarakat. Metode pengabdian masyarakat yang dilakukan meliputi 3 kegiatan, yaitu tahap persiapan dengan melakukan koordinasi dengan kedua mitra, proses pengabdian berupa edukasi literasi media dan fasilitasi teknologi, serta tahap monitoring dan evaluasi yang dilaksanakan untuk mengetahui kualitas dan kuantitas kegiatan literasi media di sekolah-sekolah dan masyarakat.

Pada tahap persiapan ditemukan beberapa hal yakni meningkatnya minat mahasiswa untuk mengikuti kegiatan edukasi literasi media. Mitra yang pada awalnya terdiri dari 2 kelompok yakni Perhumas Muda Pawitandirogo dan IMIKI Cabang Madiun akhirnya bertambah dari Himpunan Mahasiswa Ilmu Komunikasi (HIMAKOM) UNIDA Gontor. Dari hasil kesepakatan tim, ditentukan bahwa jumlah peserta keseluruhan sebanyak 30 orang. Hal ini dengan mempertimbangan efektifitas penyampaian materi kepada peserta.

Pelaksanaan kegiatan pengabdian masyarakat sudah dilakukan selama 4 bulan yaitu dari bulan April sampai dengan Juli 2017. Sesuai dengan metode kegiatan yang telah diuraikan pada tahap persiapan, pelaksanaan kegiatan dimulai awal bulan April 2017 di Universitas Darussalam Gontor.

Adapun pada tahap proses, kegiatan edukasi berupa TOT (Training of trainers) literasi media dilaksanakan pada tanggal 6 April 2017 di Universitas Darussalam Gontor. Kegiatan berlangsung sejak pagi hingga siang hari. Pemateri kegiatan adalah seorang motivator dan trainer Literasi Media dari UMM dengan jumlah peserta 30 orang. Setelah dilakukan edukasi kepada 30 peserta tersebut, tim pengabdian membentuk sebuah komunitas yang diberi nama Mahasiswa Penggerak Literasi Media (MPLM). Selanjutnya tim memberikan fasilitasi teknologi berupa LCD Proyektor untuk menunjang kegiatan sosisalisasi literasi media kepada masyarakat.

Sejak terbentuknya hingga saat ini, MPLM sudah melakukan kegiatan sosialisasi literasi media di sebuah sekolah swasta di daerah Slahung Ponorogo yang diikuti oleh sekitar 130 siswa MTs dan MA. Dalam kegiatan tersebut materi yang disampaikan berupa bagaimana menggunakan media sosial dengan baik dan dilanjutkan dengan pemutaran film yang berkaitan dengan literasi media.

Dari hasil monitoring dan evaluasi yang dilakukan oleh tim, komunitas MPLM ini menemui beberapa kendala dalam pelaksanaan kegiatan literasi media di masyarakat salah satunya berupa perijinan dan sulitnya menyepakati waktu kegiatan dengan masyarakat. Akan tetapi kendala ini sudah dicarikan jalan keluar berupa kerjasama yang dijalin oleh tim pengabdian dengan Dinas Komunikasi Informasi dan Statistik Kabupaten Ponorogo. Dinas Kominfo menyambut baik lahirnya komunitas MPLM yang bergerak dalam kegiatan sosialisasi literasi media kepada masyarakat dan akan membantu menjembatani kegiatan literasi media antara MPLM dengan masyarakat.

\section{KESIMPULAN DAN SARAN}

Diperlukan adanya kerjasama dari berbagai pihak kususnya masyarakat (komunitas/kelompok penggerak literasi media) dan unsur pemerintah untuk menggiatkan sosialisasi literasi media kepada masyarakat.

\section{DAFTAR PUSTAKA}

2009. Amandemen UUD 1945 “Perubahan Pertama Sampai Dengan Keempat. Jakarta: Bale Siasat.

http://www.kompasiana.com diakses pada tanggal 12 April 2016

http://www.nielsen.com, diakses pada tanggal 12 April 2016. 